\title{
西双版纳不同海拔热带雨林凋落量变化研究
}

\author{
郑 征 $^{1}$ 李佑荣 $^{1}$ 刘宏茂 ${ }^{1}$ 冯志立 ${ }^{1}$ 甘建民1 $^{1}$ 孔维静 $^{1,2}$ \\ （1 中国科学院西双版纳热带植物园昆明分部, 昆明 650223）（2 中国科学院研究生院, 北京 100039）
}

摘 要 在 3 个海拔梯度 (600、1 100 和 $1600 \mathrm{~m}$ ) 选取 8 块热带雨林样地, 研究了印度季风环境下西双版纳热带季节 雨林和山地雨林的调落动态随海拔的变化及其与气候的关系。在 3 个梯度上, 年平均温度分别为 22.1 、20.1 和 16. $6{ }^{\circ} \mathrm{C}$, 年平均温度递减率为 $-0.0053{ }^{\circ} \mathrm{C} \cdot \mathrm{m}^{-1}$ 。随海拔增加, 年平均降雨量增加 (分别为 1532.1659 和 $2011 \mathrm{~mm}$ ), 但 旱季的降雨量基本相同 (282 295 mm); 年蒸发量变化较小 (分别为 $1369 、 1374$ 和 $1330 \mathrm{~mm}$ ); 年平均空气相对湿度 降低 (分别为 $86 \% 、 81 \%$ 和 $84 \%$ ), 旱季后期湿度降低更明显; 样地土壤含水显著增加。热带季节雨林调落量 (1 072 $\left.\sim 1285 \mathrm{~g}^{\bullet} \mathrm{m}^{-2} \cdot \mathrm{a}^{-1}\right)$ 显著高于热带山地雨林调落量 $\left(718 \sim 1014 \mathrm{~g} \cdot \mathrm{m}^{-2} \cdot \mathrm{a}^{-1}\right)$ 。调落量和调落进程变异系数与海拔之 间存在线性显著负相关, 调落量与温度线性显著正相关而与降雨量显著负相关。旱季调落高峰受到空气相对湿度 和土壤含水量影响, 随海拔增加空气相对湿度降低使得海拔 1 105 1720 m 的调落高峰提前, 但土壤含水量继续增 加又会使调落高峰推后。研究结果得出: 1) 热带季节雨林调落量与东南亚热带潮湿雨林相近; 2) 旱季水分限制随 海拔增加而变化, 影响调落高峰出现时间;3) 随海拔增加, 热带山地雨林调落年进程由季节性向平稳过渡。

关键词＼cjkstart调落物＼cjkstart热带雨林 热带山地雨林 印度季风 西双版纳

\section{LITTERFALL OF TROPICAL RAIN FORESTS AT DIFFERENT ALTITUDES, XISHUANGBANNA, SOUTHWEST CHINA}

\author{
ZHENG Zheng $^{1}$ LI You-Rong ${ }^{1}$ LIU Hong-Mao ${ }^{1}$ FENG Zhi-Li ${ }^{1}$ GAN Jian-Min ${ }^{1}$ and KONG Wei-Jing ${ }^{1,2}$ \\ (1 Kunming Section of Xishuangbanna Tropical Botanical Garden, Chinese Academy of Sciences, Kunming 650223, China) \\ (2 Graduate School of Chinese Academy of Sciences, Beijing 100039, China)
}

\begin{abstract}
To assess the effects of the Indo monsoon on litterfall dynamics and changes of litterfall along altitudinal gradients in the tropical rain forests of southwestern China, eight plots were chosen along three elevational gradients of 600, 1100 and $1600 \mathrm{~m}$ in Xishuangbanna, China. We examined the relationship between litterfall dynamics and climate, and their changes with increasing altitude. On three gradients, average annual temperature was $22.1,20.1$ and $16.6{ }^{\circ} \mathrm{C}$ respectively, with a mean lapse rate of $-0.0053{ }^{\circ} \mathrm{C} \mathrm{m} \mathrm{m}^{-1}$. With increasing altitude, annual average rainfall increased ( 1532,1659 and $2011 \mathrm{~mm}$, respectively), while in the dry season they were similar (282-295 mm); evaporation changed slightly (1369, 1374 and $1330 \mathrm{~mm}$, respectively); annual average relative humidity decreased $(86 \%, 81 \%$ and $84 \%$, respectively) and was much more pronounced in the late dry season; and soil water content increased significantly. Litterfall production of tropical seasonal rain forest $\left(1072\right.$ to $1285 \mathrm{~g}^{\bullet} \mathrm{m}^{-2} \cdot \mathrm{a}^{-1}$ ) was higher than in the tropical montane rain forest ( 718 to $1014 \mathrm{~g} \cdot \mathrm{m}^{-2} \cdot \mathrm{a}^{-1}$ ). Both litterfall production and $C V$ of annual litterfall processes had a significant and negative linear relationship with altitude. Litterfall production had a significant and positive linear relationship with temperature and was inversely related to rainfall. Peak litterfall during the dry season was influenced by relative air humidity and soil water content. Peak litterfall occurred earlier in the dry season at altitudes of 1100 to $1720 \mathrm{~m}$ due to decreasing humidity with altitude whereas at higher sites $(1820 \mathrm{~m})$, increasing soil moisture levels delayed the litterfall peak. Our results suggested that 1) litterfall production of the tropical seasonal rain forest coincided with those of moist tropical rain forests in Southeast Asia; 2) water stress in the dry season changed with altitude and determined the timing of peak litterfall; and 3) with increasing altitude, there was a transition from seasonality to stability in annual litterfall process.
\end{abstract}

Key words Litterfall, Tropical rain forest, Tropical montane rain forest, Indo monsoon, Xishuangbanna 
森林凋落物产量和调落进程主要受到气候和森 林状况的影响。热带森林凋落物研究表明随海拔升 高引起的气候变化主要是温度降低会使凋落量减少

(Vitousek et al., 1994; Raich et al., 1997; Kitayama \& Aiba，2002)。由于受到环境中水分胁迫的影响, 调落量年进程会出现明显的季节性变化, 并会导致 森林外貌发生明显的季节性改变, 如常绿林和落叶 林, 这种差异成为森林植被分类的重要特征。总之, 森林调落物动态反映出森林生态系统的重要过程及 环境对植被的影响作用。

从亚洲低纬度热带雨林地区 (如马来西亚)向北 延伸, 季风的影响作用增强。在广大的南亚和东南 亚一带的热带,包括印度、孟加拉国、缅甸、老挝、泰 国北部、以及中国云南大部、西藏东南部和四川西南 部, 受到印度季风显著影响, 这些地区在一年中形成 了雨季与干季相互交替的气候特征 (Rai \& Procter, 1986; 杨一光, 1987; Kumar \& Deepu，1992）。关于 亚洲热带雨林调落动态的研究主要是集中在马来西 亚的热带潮湿雨林 (Anderson et al., 1983; Proctor et al., 1983; Moran et al., 2000; Kitayama \& Aiba, 2002; Takyu et al., 2003), 而印度季风气候对热带 雨林调落物影响的研究很少。虽然这些少量的研究 反映出季风环境下雨林凋落进程在旱季出现凋落高 峰( Rai \& Proctor, 1986; 郑征等, 1990; Kumar \& Deepu, 1992; Sundarapandian \& Swamy, 1999), 但限于观 测样地少, 目前仍未有概括性的结论。

热带山地雨林的结构和功能不同于低地雨林, 淮了解释这种差异, 提出了许多的假设, 它们大多数 是直接或间接与气候有关( Tanner et al. , 1998)。 些山地雨林样地的研究显示一年中最大调落量可能 出现在旱季(Edwards, 1977; Tanner, 1980; Proctor et $a l ., 1989$ )或雨季（Weaver et al., 1986）。然而, 在 哥伦比亚海拔 2550 和 $3370 \mathrm{~m}$ 的季节性降雨条件 下的山地雨林调落量在全年保持相当稳定的速率 （Veneklaas，1991）。目前还缺少对季节性气候环境 中海拔升高导致的气候变化对山地雨林调落进程影 响的研究报道。我们的问题是: 1) 与潮湿的雨林相 比,在印度季风环境下的热带雨林凋落量和凋落年 进程有何变化? 2) 在印度季风环境下, 随海拔增加 山地温度、湿度和降雨格局会发生什么变化？它对 森林调落动态有何影响? 根据已有的研究结果, 海 拔增加会导致气候变化, 以及森林调落高峰与水分 胁迫密切相关, 我们提出假设: 随海拔增加, 当旱季 对森林的水分胁迫发生时间或强度上的变化时, 反
映森林水分胁迫的调落高峰会随之发生变化。因此 通过对不同海拔水分和调落年进程的观测, 能够揭 示水分环境对森林生态系统过程的影响作用。

西双版纳位于云南省南部, 地貌结构以山原为 主。由于受到印度季风的影响, 这里的热带雨林因 上层树种在旱季末期出现换叶而被称为热带季节雨 林 (刘伦辉, 1987), 是研究印度季风环境下雨林调落 动态及山地气候变化对雨林调落动态影响的理想地 区。个别研究报道了该地区低海拔的热带季节雨林 在旱季存在调落高峰 (郑征等, 1990), 但由于缺少对 多块样地和不同海拔梯度的观测研究, 该地区热带 雨林调落量及其年进程仍不清楚。由于现有的事实 表明调节山地雨林功能的因子没有统一的模式, 对 不同地点进行深入的研究对于认识各地点之间缺少 一致性是必要的(Tanner et al., 1998)。本文的研究 目的是: 1)确定印度季风对热带雨林调落物动态的 影响；2)测定季风环境下气候和调落动态随海拔的 变化; 3) 定量研究气候因子对调落量的影响; 4)研 究旱季水分限制作用随海拔的变化及其与调落高峰 的关系。

\section{1 研究地自然概况}

西双版纳 $\left(21^{\circ} 09^{\prime} \sim 22^{\circ} 35^{\prime} \mathrm{N}, 99^{\circ} 58^{\prime} \sim 101^{\circ} 50^{\prime}\right.$ E）位于云南西南, 与老挝和缅甸接壤。这一地区处 于横断山系南端的无量山和怒山的余脉山原, 地貌 结构以山原为主, 其中分布着较多的宽谷盆地, 海拔 从 475 到 $2429.5 \mathrm{~m}$ (朱华, 2000)。这一地区位于亚 洲热带北缘, 气候受印度季风控制。在海拔相对较 低的盆地, 具有 3 个明显的季节: 湿热的雨季 $(5 \sim 10$ 月)、雾凉季 ( 11 月～翌年 2 月) 和干热季 ( $3 \sim 4$ 月)。 雾凉季和干热季合称为干季。然而, 根据我们的观 测, 在海拔高于盆地 $300 \mathrm{~m}$ 以上的山地, 在干季 11 月～翌年 2 月间不存在雾凉季。

在这一地区森林类型随海拔增高而发生变化, 热带季节雨林出现在低地和低山沟谷中（海拔 < $1000 \mathrm{~m}$ ), 热带山地雨林分布在海拔 $800 \sim 1800 \mathrm{~m}$ 的山地上。由于季风的影响, 该地每年旱季末的 3 $\sim 4$ 月, 热带雨林上层树种有一短暂而集中的换叶 期, 雨林表现出一定的季节变化, 因此这一地区的雨 林被称为热带季节雨林( 刘伦辉, 1987)。热带山地 雨林群落以热带树种为主, 间有亚热带种类混生, 外 貌和结构多具雨林特点(刘伦辉, 1987)。

在西双版纳山原海拔 600、1 100 和 $1600 \mathrm{~m}$ 的 3 个海拔梯度, 选择植被状况良好的敌仑 $(570 \mathrm{~m})$ 、补 
蛙 $(680 \mathrm{~m})$ 、象明 $(1100 \mathrm{~m})$ 和预宋 $(1600 \mathrm{~m})$ 为研究 地点。季节雨林样地设置 3 块, 其中预仑 2 块 $\left(\mathrm{ML}_{1}\right.$ 和 $\mathrm{ML}_{2}$ ), 补蚌 1 块 (BB)。 $\mathrm{ML}_{1}$ 和 $\mathrm{ML}_{2}$ 样地是以千果 榄仁( Terminalia myriocarpa)、番龙眼 ( Pometia tomentosa) 等为优势, BB 样地是以望天树 (Shorea chinensis) 为优势。山地雨林研究样地选取 5 块, 其中 1 块 (XM) 位于象明, 其它 4 块 $\left(\mathrm{MS}_{1}, \mathrm{MS}_{2}, \mathrm{MS}_{3}\right.$ 和 $\mathrm{MS}_{4}$ ) 位
于预宋。在西双版纳, 不同海拔梯度上存在完整自 然植被的山体仅存在于保护区内, 然而这些保护区 中没有足够的开阔地设置气象观测站。因此研究地 点分散在不同山地。

样地选择的标准是: 具有大树的成熟林, 森林结 构相对一致并且坡度较缓。季节雨林样地土壤为砖 红壤, 山地雨林样地为红壤。样地情况见表 1 。

表 1 西双版纳热带雨林 $\mathbf{8}$ 块观测样地的基本情况

Table 1 Description of the eight study plots in tropical rain forests in Xishuangbanna

\begin{tabular}{|c|c|c|c|c|c|c|c|}
\hline $\begin{array}{l}\text { 森林类型 } \\
\text { Forest type }\end{array}$ & $\begin{array}{c}\text { 地点 } \\
\text { Site }\end{array}$ & $\begin{array}{c}\text { 样地 } \\
\text { Plot }\end{array}$ & $\begin{array}{l}\text { 位置 } \\
\text { Location }\end{array}$ & $\begin{array}{c}\text { 海拔 } \\
\text { Altitude } \\
(\mathrm{m})\end{array}$ & $\begin{array}{c}\text { 样地面积 } \\
\text { Plot area } \\
\left(\mathrm{m}^{2}\right)\end{array}$ & $\begin{array}{c}\text { 林冠高度 } \\
\text { Canopy } \\
\text { height }(\mathrm{m})\end{array}$ & $\begin{array}{c}\text { 观测时间 } \\
\text { Observed time }\end{array}$ \\
\hline \multirow[t]{3}{*}{$\begin{array}{l}\text { 季节雨林 } \\
\text { Seasonal rain forest }\end{array}$} & $\begin{array}{c}\text { 预仑 } \\
\text { Menglun }\end{array}$ & $\mathrm{ML}_{1}$ & $\begin{array}{l}21^{\circ} 56^{\prime} 03^{\prime \prime} \mathrm{N}, \\
101^{\circ} 11^{\prime} 37^{\prime \prime} \mathrm{E}\end{array}$ & 625 & 2500 & 48 & $1999 \sim 2003$ \\
\hline & & $\mathrm{ML}_{2}$ & $\begin{array}{l}21^{\circ} 56^{\prime} \mathrm{N}, \\
101^{\circ} 11^{\prime} \mathrm{E}\end{array}$ & 650 & 2500 & 45 & $1988 \sim 1991$ \\
\hline & $\begin{array}{l}\text { 补蚌 } \\
\text { Bubeng }\end{array}$ & BB & $\begin{array}{l}21^{\circ} 37^{\prime} \mathrm{N}, \\
101^{\circ} 35^{\prime} \mathrm{E}\end{array}$ & 680 & 2500 & 60 & $1991 \sim 1992$ \\
\hline \multirow[t]{5}{*}{$\begin{array}{l}\text { 山地雨林 } \\
\text { Montane rain forest }\end{array}$} & $\begin{array}{c}\text { 象明 } \\
\text { Xiangming }\end{array}$ & XM & $\begin{array}{l}22^{\circ} 06^{\prime} 10^{\prime \prime} \mathrm{N}, \\
101^{\circ} 20^{\prime} 29^{\prime \prime} \mathrm{E}\end{array}$ & 1105 & 2500 & 30 & $1999 \sim 2003$ \\
\hline & $\begin{array}{c}\text { 预宋 } \\
\text { Mengsong }\end{array}$ & $\mathrm{MS}_{1}$ & $\begin{array}{l}21^{\circ} 29^{\prime} 35^{\prime \prime} \mathrm{N}, \\
100^{\circ} 30^{\prime} 27^{\prime \prime} \mathrm{E}\end{array}$ & 1610 & 2500 & 30 & $1999 \sim 2003$ \\
\hline & & $\mathrm{MS}_{2}$ & $\begin{array}{l}21^{\circ} 30^{\prime} 38^{\prime \prime} \mathrm{N}, \\
100^{\circ} 30^{\prime} 03^{\prime \prime} \mathrm{E}\end{array}$ & 1720 & 2500 & 30 & $1999 \sim 2003$ \\
\hline & & $\mathrm{MS}_{3}$ & $\begin{array}{l}21^{\circ} 30^{\prime} 38^{\prime \prime} \mathrm{N}, \\
100^{\circ} 30^{\prime} 10^{\prime \prime} \mathrm{E}\end{array}$ & 1720 & 2500 & 30 & $2002 \sim 2003$ \\
\hline & & $\mathrm{MS}_{4}$ & $\begin{array}{l}21^{\circ} 30^{\prime} 47^{\prime \prime} \mathrm{N}, \\
100^{\circ} 29^{\prime} 54^{\prime \prime} \mathrm{E}\end{array}$ & 1820 & 2500 & 25 & $2002 \sim 2003$ \\
\hline
\end{tabular}

\section{2 研究方法}

\section{1 气象观测}

预仑的气象数据由中国科学院生态系统研究网 络西双版纳预仑热带雨林定位观测站提供。补蛙样 地与预仑海拔接近, 采用㔚仑气象数据。该地区缺 少山地气象观测数据, 我们在象明和㔚宋设立气象 观测点, 观测点位置见表 2 。每个点安放百叶箱, 其 内放置干球、湿球、最高和最低温度计, 并放置地表 温度计、土壤温度计、雨量计和蒸发血。观测从 2001 年 12 月 31 日 20:00 点正式开始, 按照常规气 象观测每日进行观测。

\section{2 调落物}

在每个样地中设置面积为 $0.25 \mathrm{~m}^{2}$ 的网眼为 $0.1 \mathrm{~mm}$ 的圆雉形收集框 16 个, 排成 4 行, 编号, 每 个之间的距离为 $10 \mathrm{~m}$, 框口离地面 $1 \mathrm{~m}$ 。在每月 15 日和月末进行收集, 分别装入布袋, 每个收集框的样 品分别分为叶、枝、花、果、皮、碎屑(包括不能分辨的
和一些附生物), 在 $80{ }^{\circ} \mathrm{C}$ 下烘干, 称重。由于调落物 样品处理工作量大, 样地的设立时间不同。 $\mathrm{ML}_{1}$, $\mathrm{XM}, \mathrm{MS}_{1}$ 和 $\mathrm{MS}_{2}$ 样地是在 1999 年 1 月设立。 $\mathrm{MS}_{3}$ 和 $\mathrm{MS}_{4}$ 在 2002 年 1 月设立。另外, 还利用了 1988 年设 立的 $\mathrm{ML}_{2}$ 和 1990 年设立的 $\mathrm{BB}$ 样地的观测数据。各 样地观测期见表 1 。

\section{3 土壤含水量}

在 $\mathrm{ML}_{1} 、 \mathrm{ML}_{2} 、 \mathrm{MS}_{1} 、 \mathrm{MS}_{3}$ 和 $\mathrm{MS}_{4}$ 等 5 块样地中各 选取 3 个点, 对土壤进行取样, 取样深度为 $10 、 20$ 、 40、60、80 和 $100 \mathrm{~cm}$ 。样品在 $105{ }^{\circ} \mathrm{C}$ 下烘干, 测含水 量。取样时间为 2003 年 1 月 15 日和 3 月 15 日。

\section{4 数据统计}

图 1 和表 2 中的气象观测数据是 3 个梯度从 2002 到 2004 年的 3 年平均值。土壤含水量图(图 2) 显示各样地 $0 \sim 100 \mathrm{~cm}$ 土壤含水量平均值和每次调 查时 3 次重复取样的标准误差。调落物平均值的标 准误差显示各样地观测期间的年变化和月变化。在 8 块样地之间, 总调落量差异进行了一元方差 (ANO- 
$\mathrm{VA})$ 分析和多重比较 $(L S D, p=0.05)$ 。月调落量变 异系数计算公式为: $C V=(S D / X) \times 100 \%, X$ 为观 测期月调落量平均值, $S D$ 为观测期月调落量平均值 标准差。热带季节雨林和山地雨林在调落量和月调 落量变异系数的平均值的差异进行了一元方差 (ANOVA) 分析和多重比较 $(L S D, p=0.05)$ 。气象因 子变化与海拔之间关系进行了线性回归分析。利用 线性回归对生态系统性质(调落量和年调落进程变异 系数)与气候因子和海拔的关系进行了定量分析。在 回归分析中, 8 块样地海拔为实际测量结果, 但样地 气象数据只能采用样地所处梯度的气象观测数据。

\section{3 结 果}

\subsection{3 个海拔梯度的气候}

3 个海拔梯度的气候条件见表 2 。3 个海拔梯 度年平均温度为 $16.6 \sim 22.1{ }^{\circ} \mathrm{C}$, 年平均温度随海拔 增高线性降低, 年平均温度的递减率为 $-0.0053{ }^{\circ} \mathrm{C}$ $\cdot \mathrm{m}^{-1}$ (表 3 )。随海拔增加, 年降雨量明显增加, 而年 蒸发量和空气相对湿度呈降低趋势 (表 2)。3 个梯 度的最低平均月温出现在 12 月(象明和预宋)或 1
月(预仑), 最高平均月温出现在 6 月 (图 1)。在 12 月～翌年 4 月间, 海拔 $1105 \mathrm{~m}$ 的月平均温度与 570 $\mathrm{m}$ 的接近(图 1)。3 个梯度降雨量年进程一致, 5 月 开始急剧增加, 9 月后迅速减少, 显示出印度季风的 影响作用(图 1)。旱季 3 个梯度的降雨量很接近, 为 $282 \sim 295 \mathrm{~mm}$ (表 2)。在 $2 \sim 4$ 月间, 3 个梯度空气 相对湿度明显降低, 尤其是在山地海拔 1105 和 $1610 \mathrm{~m}$ 的相对湿度降低更强烈 (图 1)。此时蒸发 量急剧增加, 海拔越高蒸发越大(图 1)。蒸发量和 相对湿度沿海拔的变化显示出旱季山地雨林的空气 水分条件比季节雨林的更加亏缺。由于只有 3 个梯 度, 表 3 中一些回归关系达不到显著水平, 但除年 平均相对湿度外, 温度、降水和蒸发与海拔之间的相 关系数都很高 (表 3 )。

\section{2 土壤含水量}

旱季不同海拔 5 块样地的土壤含水量见图 2,1 月 5 块样地土壤含水量为 $11 \% \sim 35 \%$, 海拔 $625 \mathrm{~m}$ $\left(\mathrm{ML}_{1}\right)$ 样地的土壤含水量低, $S E$ 很小, $1820 \mathrm{~m}\left(\mathrm{MS}_{4}\right)$ 的含水量最高。3 月各样地的土壤含水量都分别 比 1 月降低, 其中海拔 $625 \mathrm{~m}\left(\mathrm{ML}_{1}\right), 650 \mathrm{~m}\left(\mathrm{ML}_{2}\right)$ 和

表 2 西双版纳 3 个海拔梯度 $2002 \sim 2004$ 年的气象观测数据平均值

Table 2 Climate data for the study sites at three altitudinal gradients in Xishuangbanna, values are mean of 2002 to 2004

\begin{tabular}{|c|c|c|c|c|c|c|c|c|c|}
\hline $\begin{array}{l}\text { 地点 } \\
\text { Site }\end{array}$ & $\begin{array}{c}\text { 位置 } \\
\text { Location }\end{array}$ & $\begin{array}{l}\text { 海拔 } \\
\text { Altitude } \\
(\mathrm{m})\end{array}$ & $\begin{array}{l}\text { 年平均 } \\
\text { 温度 } \\
\text { Mean annu- } \\
\text { al tempera- } \\
\text { ture }\left({ }^{\circ} \mathrm{C}\right)\end{array}$ & $\begin{array}{l}\text { 年平均最 } \\
\text { 高温度 } \\
\text { Mean annu- } \\
\text { al maximum } \\
\text { temperature } \\
\left({ }^{\circ} \mathrm{C}\right)\end{array}$ & $\begin{array}{l}\text { 年平均最 } \\
\text { 低温度 } \\
\text { Mean annu- } \\
\text { al minimum } \\
\text { temperature } \\
\left({ }^{\circ} \mathrm{C}\right)\end{array}$ & $\begin{array}{l}\text { 年平均降 } \\
\text { 雨量 } \\
\text { Mean annu- } \\
\text { al rainfall } \\
\text { ( } \mathrm{mm} \text { ) }\end{array}$ & $\begin{array}{l}\text { 干季降 } \\
\text { 雨量 } \\
\text { Rainfall in } \\
\text { the dry sea- } \\
\text { son ( } \mathrm{mm} \text { ) }\end{array}$ & $\begin{array}{l}\text { 年平均蒸 } \\
\text { 发量 } \\
\text { Mean annu- } \\
\text { al evapora- } \\
\text { tion ( } \mathrm{mm} \text { ) }\end{array}$ & $\begin{array}{l}\text { 年平均相 } \\
\text { 对湿度 } \\
\text { Mean annu- } \\
\text { al relative } \\
\text { humidity } \\
(\%)\end{array}$ \\
\hline $\begin{array}{l}\text { 秒仑 } \\
\text { Menglun }\end{array}$ & $\begin{array}{l}21^{\circ} 56^{\prime} \mathrm{N}, \\
101^{\circ} 11^{\prime} \mathrm{E}\end{array}$ & 570 & 22.1 & 29.5 & 18.4 & 1531.7 & 289.5 & 1369.4 & 85.9 \\
\hline $\begin{array}{l}\text { 象明 } \\
\text { Xiangming }\end{array}$ & $\begin{array}{l}22^{\circ} 06^{\prime} \mathrm{N}, \\
101^{\circ} 20^{\prime} \mathrm{E}\end{array}$ & 1105 & 20.1 & 26.0 & 16.3 & 1658.5 & 295.0 & 1373.6 & 80.9 \\
\hline $\begin{array}{l}\text { 预宋 } \\
\text { Mengsong }\end{array}$ & $\begin{array}{l}21^{\circ} 29^{\prime} \mathrm{N}, \\
100^{\circ} 30^{\prime} \mathrm{E}\end{array}$ & 1610 & 16.6 & 21.9 & 12.8 & 2011.1 & 282.4 & 1329.7 & 83.6 \\
\hline
\end{tabular}

表 3 研究地点气象数据和样地土壤含水量与海拔间的直线回归分析

Table 3 Summaries of linear regressions of climate data on the three study sites and soil water content at five plots against altitude $(\mathrm{m})$

\begin{tabular}{lccc}
\hline \multicolumn{1}{c}{ 变量 Dependent } & 截距 Intercept & 斜率 Slope & $R^{2}$ \\
\hline 年平均温度 Mean annual temperature $\left({ }^{\circ} \mathrm{C}\right)$ & 25.374 & -0.0053 & 0.9704 \\
年平均最高温度 Mean annual maximum temperature $\left({ }^{\circ} \mathrm{C}\right)$ & 33.933 & -0.0074 & $0.9971^{*}$ \\
年平均最低温度 Mean annual minimum temperature $\left({ }^{\circ} \mathrm{C}\right)$ & 21.714 & -0.0054 & 3 \\
年平均降雨量 Mean annual rainfall $(\mathrm{mm})$ & 1231.4 & 0.4587 & 0.9746 \\
年平均蒸发量 Mean annual evaporation $(\mathrm{mm})$ & 1397.3 & -19.85 & 0.9225 \\
年平均相对湿度 Mean annual relative humidity $(\%)$ & 85.767 & -1.15 & 0.6714 \\
1 月土壤含水量 Soil water content in January $(\%)$ & 4.5971 & 5.8094 & 0.2111 \\
3月土壤含水量 Soil water content in March $(\%)$ & 2.5648 & 5.1228 & 3 \\
\hline
\end{tabular}



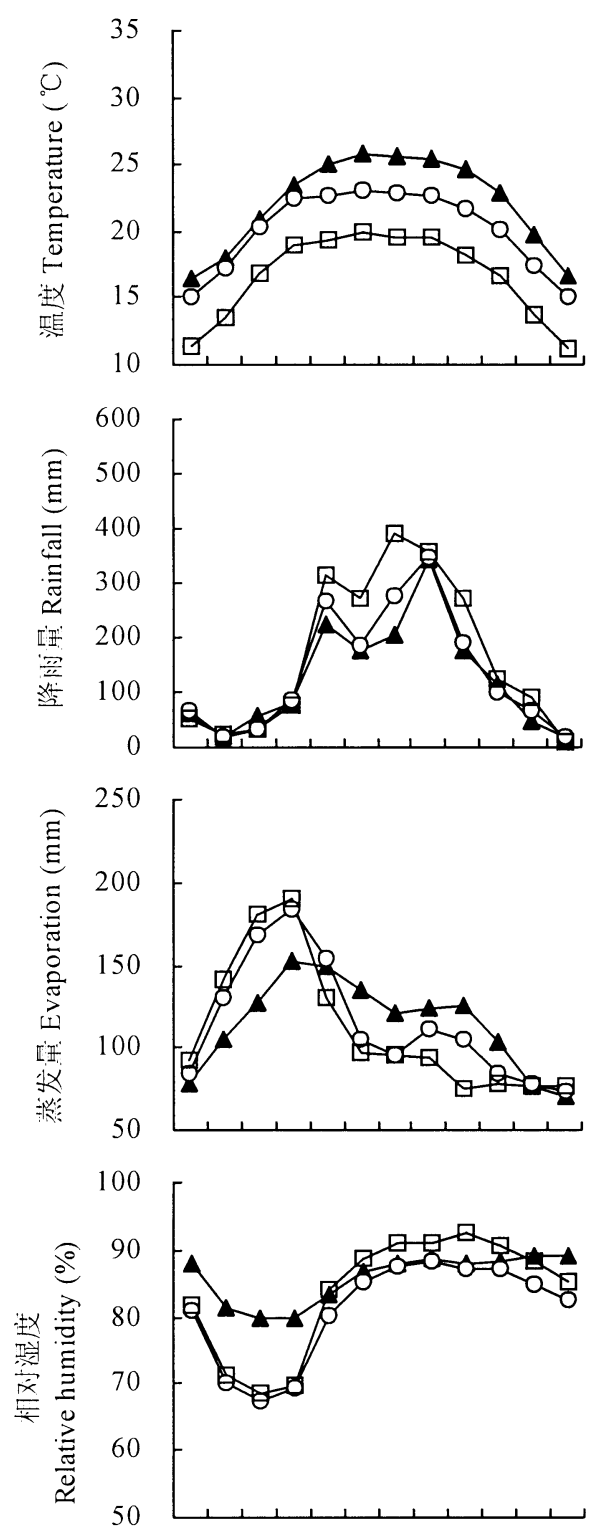

$\begin{array}{llllllllll}1 & 2 & 3 & 4 & 5 & 6 & 7 & 8 & 9 & 101112\end{array}$

月份 Month

$\longrightarrow 570 \mathrm{~m} \rightarrow-1105 \mathrm{~m} \square-1610 \mathrm{~m}$

图 1 西双版纳 3 个海拔梯度的月平均气温、降雨量、 蒸发量和空气相对湿度的年进程(2002 2004)

Fig. 1 Annual processes of mean monthly air temperatures, rainfall, evaporation and air relative humidity on three research altitudinal gradients in Xishuangbanna during $2002-2004$

海拔 $570 \mathrm{~m}$ 的数据由中国科学院西双版纳热带雨林定位观测站 提供 Data of altitude $570 \mathrm{~m}$ are determined by the Xishuangbanna Research Station of the Tropical Rain Forest Ecosystem, the Chinese Academy of Sciences

$1820 \mathrm{~m}\left(\mathrm{MS}_{4}\right)$ 的降低达到显著水平 $(p<0.01)$ 。随 海拔升高, 1 和 3 月的土壤含水量都呈线性显著增 加 $(p<0.01$, 表 3$)$, 旱季土壤水分条件随海拔的变 化与空气水分条件的变化相反。

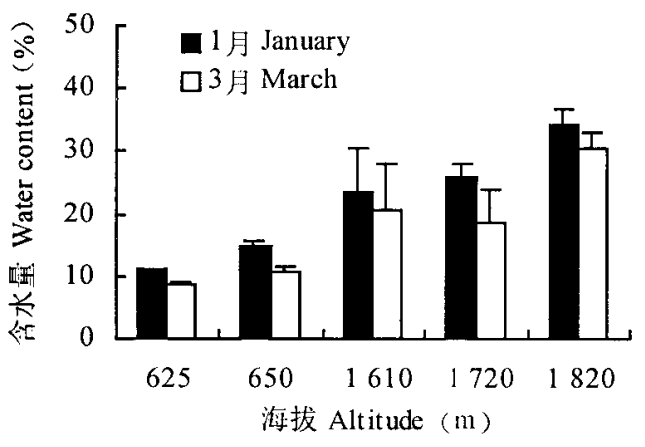

图 2 西双版纳不同海拔 5 块样地旱季 $0 \sim 100 \mathrm{~cm}$ 深度的土壤含水量

Fig.2 Soil water content at $0-100 \mathrm{~cm}$ depth on five plots with different altitudes in Xishuangbanna in the dry season

\section{3 调落量}

8 块样地调落量为 $718 \sim 1285 \mathrm{~g} \cdot \mathrm{m}^{-2} \cdot \mathrm{a}^{-1}$ (表 4), 主要组分为叶和枝, 叶占调落量的 $56 \% \sim 71 \%$, 枝占 $12 \% \sim 20 \%$ 。果实的比例差异较大, $\mathrm{XM}$ 和 $\mathrm{BB}$ 分别仅占 $2.5 \%$ 和 $3.0 \%, \mathrm{ML}_{2}$ 达 $16.8 \%$ 。花和树皮 的比例分别为 $0.3 \% \sim 6.0 \%$ 和 $0.4 \% \sim 4.9 \%$, 碎屑 为 $5.6 \% \sim 12.9 \%$ 。季节雨林 $\mathrm{ML}_{1}$ 和 $\mathrm{ML}_{2}$ 之间总调 落量差异不显著, 山地雨林样地中 $\mathrm{MS}_{1}$ 和 $\mathrm{MS}_{2}$ 调落 量与季节雨林样地 $\mathrm{ML}_{1}$ 和 $\mathrm{ML}_{2}$ 存在显著差异 (表 4)。山地雨林样地之间, $\mathrm{MS}_{1}$ 显著低于 $\mathrm{XM}, \mathrm{MS}_{3}$ 和 $\mathrm{MS}_{4} ; \mathrm{MS}_{2}$ 显著低于 $\mathrm{XM}$ (表 4)。

3 块季节雨林总调落量平均值 $\left(1156 \mathrm{~g} \cdot \mathrm{m}^{-2}\right.$ ・ $\left.\mathrm{a}^{-1}\right)$ 较山地雨林的高 $27.2 \%$, 差异显著 $(p<0.05)$, 树皮调落量也高于山地雨林 $(p<0.01)$, 但叶、枝、 花、果和杂物的调落量与山地雨林差异都达不到显 著水平(表 4)。

\section{4 调落年进程}

在旱季 8 块样地的调落量增加（图 3)。3 块季 节雨林样地中, $\mathrm{ML}_{1}$ 和 $\mathrm{ML}_{2}$ 样地在旱季 $3 \sim 4$ 月总调 落量出现明显的调落高峰, 调落高峰期主要成分为 叶, 2 个月的叶调落量分别占各自年叶调落量的 $55.6 \%$ 和 $50.4 \%$; BB 样地除 3 4 月出现叶调落高 峰外, 在 $6 \sim 7$ 月还存在一较弱的叶调落高峰, 两个 高峰期的叶调落量分别占年调落量的 $36.4 \%$ 和 $23.7 \%$ 。3 块样地最大月调落量为 $223 \sim 275 \mathrm{~g} \cdot \mathrm{m}^{-2}$, 番龙眼林 $\left(\mathrm{ML}_{1}\right.$ 和 $\left.\mathrm{ML}_{2}\right)$ 的最大月调落量出现在 4 月, 晚于望天树林 (BB) 的 (3 月)。除 $\mathrm{MS}_{4}$, 其它山地 雨林样地调落高峰出现的时间较季节雨林更早, 持 续时间也更长。 $\mathrm{MS}_{1}$ 的调落高峰出现在 $1 \sim 4$ 月, 高 峰期叶调落量占年叶调落量的 $59.1 \% ; \mathrm{MS}_{2}$ 的调落 
表 4 西双版纳热带雨林 8 块样地的调落量年平均值 \pm 标准误差

Table 4 Annual litterfall means $\pm S E\left(\mathrm{~g}^{\bullet} \mathrm{m}^{-2} \cdot \mathrm{a}^{-1}\right)$ in the eight plots of tropical rain forests in Xishuangbanna

\begin{tabular}{ccccccccc}
\hline $\begin{array}{c}\text { 森林类型 } \\
\text { Forest type }\end{array}$ & $\begin{array}{c}\text { 样地 } \\
\text { Plot }\end{array}$ & $\begin{array}{c}\text { 叶 } \\
\text { Leaves }\end{array}$ & $\begin{array}{c}\text { 枝 } \\
\text { Branches }\end{array}$ & $\begin{array}{c}\text { 花 } \\
\text { Flowers }\end{array}$ & $\begin{array}{c}\text { 果 } \\
\text { Fruits }\end{array}$ & $\begin{array}{c}\text { 杂物 } \\
\text { Trash }\end{array}$ & $\begin{array}{c}\text { 皮 } \\
\text { Bark }\end{array}$ & $\begin{array}{c}\text { 总 } \\
\text { Total }\end{array}$ \\
\hline 季节雨林 Seasonal rain forest & $\mathrm{ML}_{1}$ & $614 \pm 16$ & $185 \pm 12$ & $6 \pm 2$ & $97 \pm 40$ & $109 \pm 15$ & $61 \pm 8$ & $1072 \pm 65^{\mathrm{a}}$ \\
& $\mathrm{ML}_{2}$ & $624 \pm 107$ & $188 \pm 21$ & $23 \pm 6$ & $186 \pm 110$ & $63 \pm 7$ & $27 \pm 3$ & $1112 \pm 15^{\mathrm{a}}$ \\
& $\mathrm{BB}$ & 916 & 181 & 4 & 38 & 102 & 44 & 1285 \\
平均 Mean & $718 \pm 99^{\mathrm{a}}$ & $185 \pm 2^{\mathrm{a}}$ & $11 \pm 6^{\mathrm{a}}$ & $107 \pm 43^{\mathrm{a}}$ & $91 \pm 14^{\mathrm{a}}$ & $44 \pm 9^{\mathrm{a}}$ & $1156 \pm 65^{\mathrm{a}}$ \\
& $\mathrm{XM}$ & $647 \pm 29$ & $208 \pm 33$ & $22 \pm 3$ & $26 \pm 5$ & $130 \pm 11$ & $6 \pm 2$ & $1040 \pm 54^{\mathrm{a}}$ \\
& $\mathrm{MS}_{1}$ & $430 \pm 13$ & $113 \pm 15$ & $16 \pm 8$ & $63 \pm 10$ & $92 \pm 11$ & $3 \pm 1$ & $718 \pm 38^{\mathrm{c}}$ \\
& $\mathrm{MS}_{2}$ & $526 \pm 19$ & $107 \pm 4$ & $53 \pm 9$ & $90 \pm 34$ & $90 \pm 9$ & $4 \pm 4$ & $869 \pm 42^{\mathrm{bc}}$ \\
& $\mathrm{MS}_{3}$ & $532 \pm 29$ & $188 \pm 40$ & $43 \pm 2$ & $69 \pm 23$ & $73 \pm 5$ & $19 \pm 8$ & $924 \pm 61^{\mathrm{ab}}$ \\
& $\mathrm{MS}_{4}$ & $656 \pm 2$ & $172 \pm 19$ & $21 \pm 12$ & $53 \pm 29$ & $82 \pm 00$ & $11 \pm 1$ & $995 \pm 5^{\mathrm{ab}}$ \\
& 平均 Mean & $558 \pm 42^{\mathrm{a}}$ & $158 \pm 20^{\mathrm{a}}$ & $31 \pm 7^{\mathrm{a}}$ & $60 \pm 10^{\mathrm{a}}$ & $93 \pm 10^{\mathrm{a}}$ & $9 \pm 3^{\mathrm{b}}$ & $909 \pm 56^{\mathrm{b}}$ \\
\hline
\end{tabular}

8 块样地的调落量之间、以及季节雨林与山地雨林调落量平均值之间的差异显著性分别进行了方差分析, 字母不同表示差异显著 The significance of difference of litterfall among the eight plots and between seasonal rain forest and montane rainforest are shown. Different letter indicate significant difference (ANOVA, $L S D$ multiple comparisons $L S D, p=0.05$ ) 除 BB 样地为 1 年的观测数据, 其它样地均为多年的观测数据 For plot BB, only one year data was available

表 5 西双版纳热带雨林 8 块样地月调落量的变异系数

Table 5 Coefficients of variation $(\mathrm{CV})$ of monthly litterfall in the eight plots of tropical rain forests in Xishuangbanna

\begin{tabular}{|c|c|c|c|c|c|c|}
\hline $\begin{array}{l}\text { 森林类型 } \\
\text { Forest type }\end{array}$ & $\begin{array}{l}\text { 样地 } \\
\text { Plot }\end{array}$ & $\begin{array}{c}\text { 叶 } \\
\text { Leaves }\end{array}$ & $\begin{array}{c}\text { 枝 } \\
\text { Branches }\end{array}$ & $\begin{array}{c}\text { 花 } \\
\text { Flowers }\end{array}$ & $\begin{array}{c}\text { 果 } \\
\text { Fruits }\end{array}$ & $\begin{array}{c}\text { 总 } \\
\text { Total }\end{array}$ \\
\hline \multirow[t]{4}{*}{ 热带季节雨林 Seasonal rain forest } & $\mathrm{ML}_{1}$ & 114 & 83 & 140 & 160 & 81 \\
\hline & $\mathrm{ML}_{2}$ & 103 & 81 & 117 & 99 & 73 \\
\hline & $\mathrm{BB}$ & 68 & 66 & 271 & 238 & 52 \\
\hline & $\begin{array}{c}\text { 平均值 } \pm S E \\
\text { Mean } \pm S E\end{array}$ & $95 \pm 14^{\mathrm{a}}$ & $77 \pm 5^{\mathrm{a}}$ & $176 \pm 48^{\mathrm{a}}$ & $166 \pm 40^{\mathrm{a}}$ & $69 \pm 9^{\mathrm{a}}$ \\
\hline \multirow[t]{6}{*}{ 热带山地 Montane rain forest } & XM & 65 & 45 & 168 & 61 & 51 \\
\hline & $\mathrm{MS}_{1}$ & 61 & 65 & 187 & 47 & 44 \\
\hline & $\mathrm{MS}_{2}$ & 61 & 52 & 163 & 149 & 46 \\
\hline & $\mathrm{MS}_{3}$ & 62 & 84 & 141 & 115 & 51 \\
\hline & $\mathrm{MS}_{4}$ & 61 & 90 & 137 & 97 & 51 \\
\hline & $\begin{array}{c}\text { 平均值 } \pm S E \\
\text { Mean } \pm S E\end{array}$ & $62 \pm 1^{\mathrm{b}}$ & $67 \pm 9^{a}$ & $159 \pm 9^{a}$ & $93 \pm 18^{\mathrm{a}}$ & $49 \pm 2^{b}$ \\
\hline
\end{tabular}
$=0.05$ )

高峰出现在 1 3 月, 高峰期叶调落量占全年的 57 . $8 \%$; XM 和 $\mathrm{MS}_{3}$ 调落高峰出现在 2 4 月, 高峰期叶 调落量分别占各自年调落量的 $51.5 \%$ 和 $49.5 \%$ 。 $\mathrm{MS}_{4}$ 样地调落高峰出现在 3 4 月, 与季节雨林类 似, 高峰期叶调落量占年叶调落量的 $36.7 \%$ 。山地 雨林高峰期最大月调落量为 $103 \sim 172 \mathrm{~g} \cdot \mathrm{m}^{-2}$, 较季 节雨林低。

季节雨林花调落量都很低, $\mathrm{ML}_{2}$ 和 $\mathrm{BB}$ 花调落出 现在 3 月, 但 $\mathrm{ML}_{1}$ 在 6 月观测到较高的花调落量。 山地雨林样地在 2 4 月花调落量高, 但一些样地在 5 和 6 月也观测到较高的花调落量。季节雨林果调 落高峰都出现在 $7 \sim 9$ 月, 此时果成熟。山地雨林
中, $\mathrm{MS}_{2}$ 和 $\mathrm{MS}_{4}$ 在 $9 \sim 11$ 月出现明显果调落高峰, 较 季节雨林的晚; $\mathrm{MS}_{3}$ 在 6 月和 $10 \sim 12$ 月的果调落量 较高; XM 和 $\mathrm{MS}_{1}$ 果调落高峰不明显(图 3)。

\section{5 月调落量变异系数及其随海拔变化}

季节雨林样地叶调落量月变异系数平均值显著 高于山地雨林的 $(p<0.05)$, 总调落量的月变异系数 也高于山地雨林 $(p<0.05)$, 但两种林之间, 花、果、 枝的月调落变异系数差异不显著 (表 5)。8 块样地 叶和总调落物的月调落量变异系数随海拔升高呈幂 函数显著降低( 叶 $p<0.01$, 总 $p<0.05$, 图 4)。

\section{6 调落量与海拔、年平均温度和降雨量}

随海拔升高, 总调落量呈线性显著降低 $(p<$ 
(A)
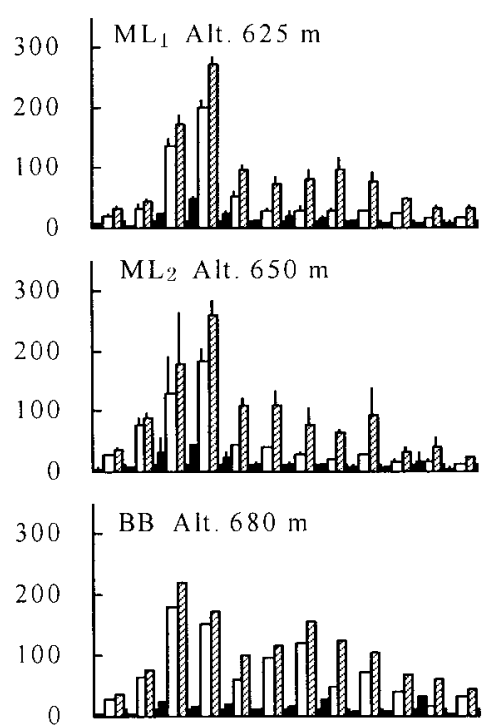

年

XM Alt. $1105 \mathrm{~m}$

$$
\begin{aligned}
& 2 \\
& 100 \\
& 3 \\
& 200 \\
& 100
\end{aligned}
$$

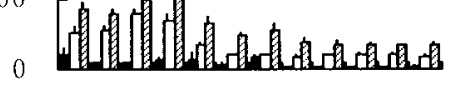
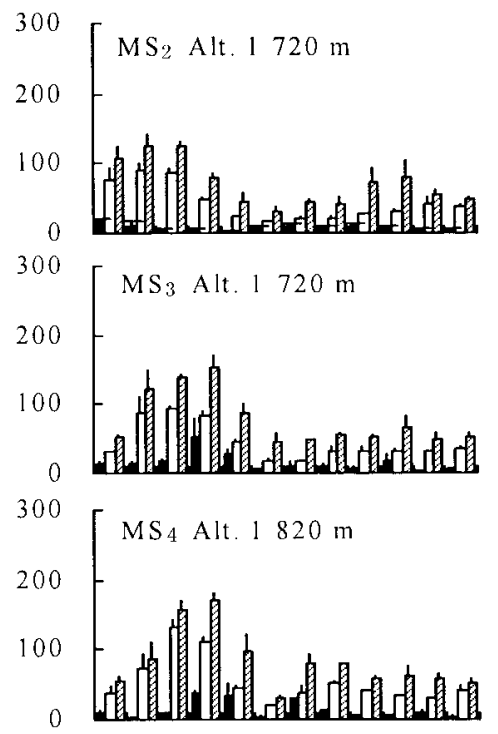

122344567789101112
(B)
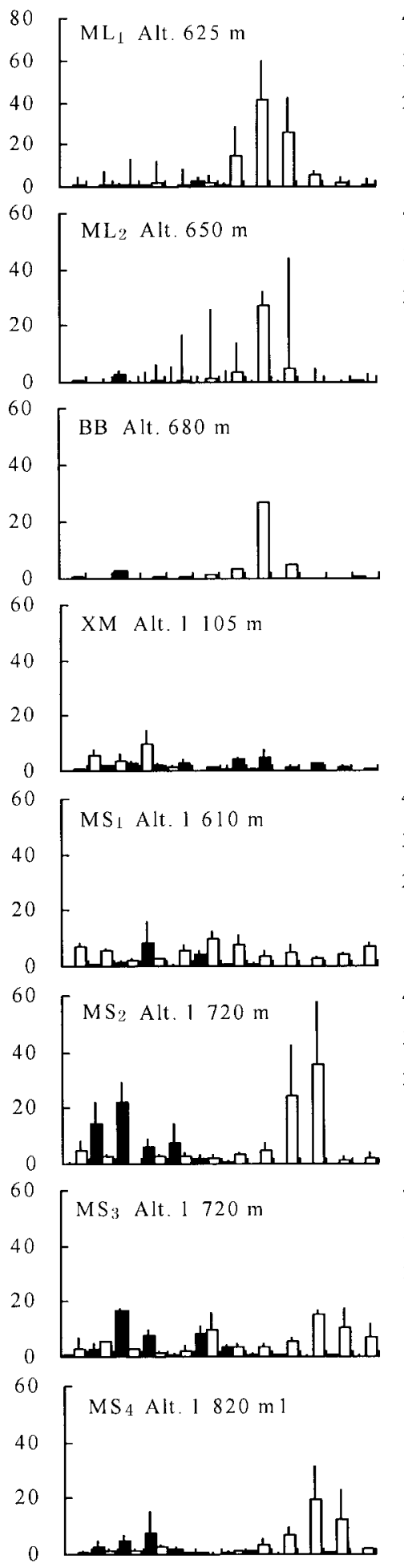

$123 \quad 3 \quad 4 \quad 5 \quad 6 \quad 7 \quad 899101112$
(C)
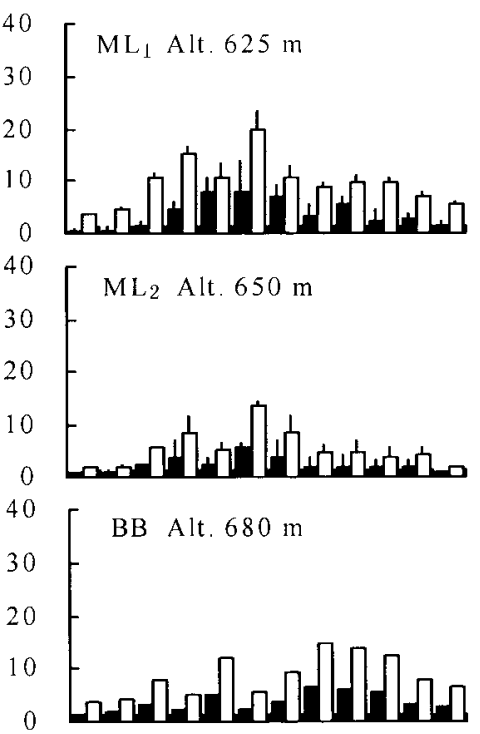

40
30
20
10
0
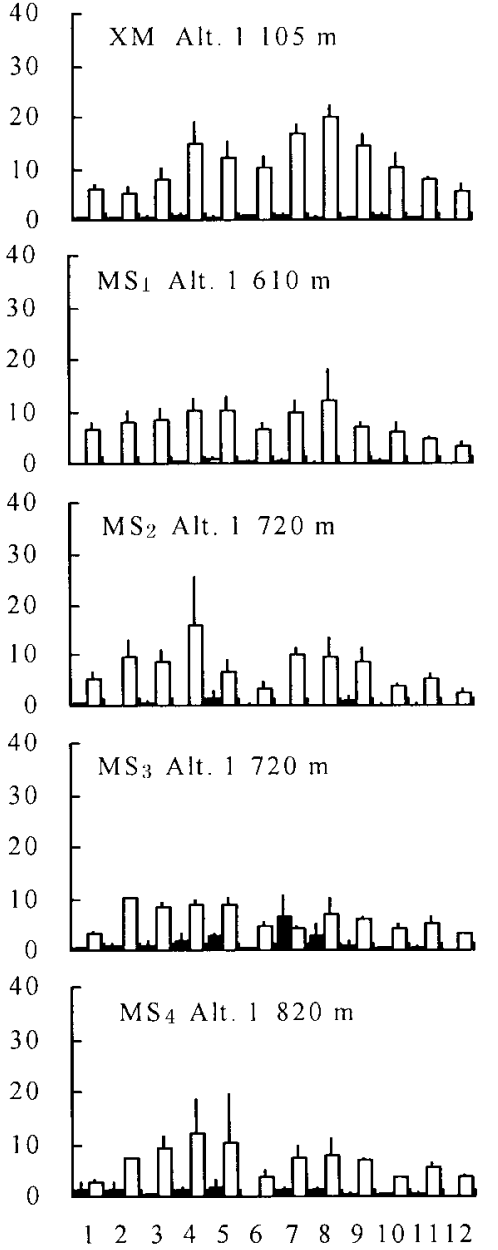

月份 Month 
$0.05)$; 随年均温度上升, 总调落量呈线性显著增加 $(p<0.05)$; 总调落量与降雨量还存在显著负相关 $(p<0.05)$ (图 5)。

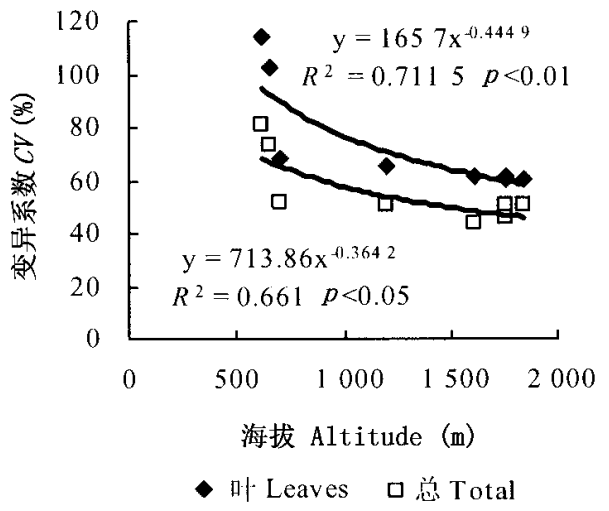

图 4 西双版纳热带雨林 8 块样地的总调落和 叶调落量月变异系数随海拔变化

Fig.4 Coefficients of variation ( $\mathrm{CV}$ ) of monthly leaf and total litterfall along gradients in altitude in the eight plots of tropical rain forests in Xishuangbanna

\section{4 讨 论}

\section{1 与其它雨林调落量的比较}

一些研究显示世界范围内森林调落物产量与纬 度之间存在负的线性相关 (Bray \& Gorham, 1964; Vogt et al., 1986), 这主要是由于调落量与生长季的 光照存在很强的相关关系 (Jordan, 1971)。最高的 调落量出现在热带阔叶落叶林和常绿林 (Vogt et $a l$, 1986)。在东南亚热带雨林观测到很高的调落 量, 马来西亚沙捞越 4 种热带雨林调落量分别为 880、920、1 150 和 $1200 \mathrm{~g} \cdot \mathrm{m}^{-2} \cdot \mathrm{a}^{-1}$ (Proctor et al., 1983)。马来西亚婆罗洲 3 块雨林调落量分别为 $1105 、 1110$ 和 $1113 \mathrm{~g} \cdot \mathrm{m}^{-2} \cdot \mathrm{a}^{-1}$ (Burghouts et al., 1998; Kitayama \& Aiba, 2002)。文莱热带龙脑香雨 林和石南林 (Heath forest) 的调落量分别为 827 和 817 $\mathrm{g} \cdot \mathrm{m}^{-2} \cdot \mathrm{a}^{-1}$ (Moran et al., 2000)。本研究热带季节 雨林 3 块样地的调落量都很高, 为 $1072 \sim 1285 \mathrm{~g}$ • $\mathrm{m}^{-2} \cdot \mathrm{a}^{-1}$, 显示季风环境下的西双版纳热带季节雨 林调落量与东南亚热带雨林的接近。

4.2 海拔增加与调落量变化

一些观测显示热带雨林调落量随海拔升高而降 低(Veneklaas，1991；Kitayama \& Aiba，2002), 马来西 亚海拔 $700 \sim 3100 \mathrm{~m}$ 范围的生长在两种基质上的热 带山地雨林调落量均随海拔增高呈线性降低: $L=$
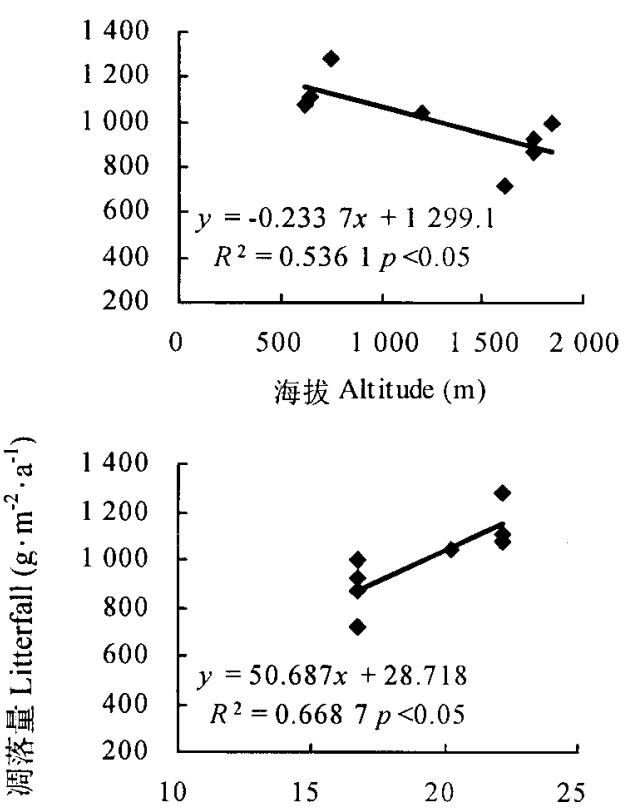

温度 Temperat ure $\left({ }^{\circ} \mathrm{C}\right)$

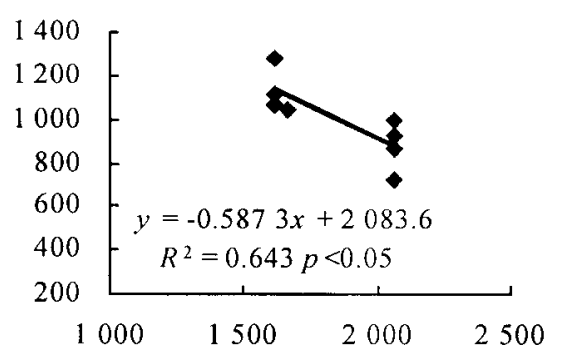

降雨量 Rainfall (mm)

图 5 西双版纳热带雨林 8 块样地年调落量随 海拔、温度和降雨的变化

Fig.5 Changes of litterfall along gradients in altitude, temperature and rainfall in the eight plots of tropical rain forests in Xishuangbanna

+1 348(超基性岩上)(Kitayama \& Aiba，2002)。在 夏威夷 Mauna Loa 热带雨林, 随海拔增加 (290 1 $660 \mathrm{~m}$ ) 调落量线性显著降低（Raich et al.，1997）。 随森林不同回归模型参数会发生变化, 但随海拔增 加西双版纳热带雨林调落量的线性下降 (斜率 $=-$ 0.2337 , 截距 $=1299.1$, 图 5) 与马来西亚生长在沉 积岩上的热带雨林相近。然而, 预宋 4 块样地海拔 为 $1610 、 1720 、 1720$ 和 $1820 \mathrm{~m}$, 调落量分别为 718 、 869、924 和 $995 \mathrm{~g} \cdot \mathrm{m}^{-2} \cdot \mathrm{a}^{-1}$, 随海拔增加调落量增加, 其变化与整个梯度的相反。这种局部变化的原因之 一是海拔 $1610 \mathrm{~m}$ 的样地曾经受到较强的干扰, 样 地中部存在林窗, 另外样地位于沟谷, 日照时间相对 短。这一情况说明在同一梯度范围内的调落物观测 中选取 1 块以上的样地是必要的。

哀牢山位于西双版纳北部, 也属横断山脉。在 
海拔 $2500 \mathrm{~m}$ 观测地, 年平均温度为 $11.3{ }^{\circ} \mathrm{C}$, 年降雨 量为 $1931 \mathrm{~mm}$, 该地的山地常绿阔叶林两块样地的 调落量为 540 和 $710 \mathrm{~g} \cdot \mathrm{m}^{-2} \cdot \mathrm{a}^{-1}$ ( Liu et al ., 2002a)。 根据本研究和哀牢山的观测结果, 从西双版纳海拔 600、1 100 和 $1600 \mathrm{~m}$ 到哀牢山 $2500 \mathrm{~m}$, 森林调落量 $(L)$ 与年平均温度 $(T)$ 存在显著线性正相关 $(L=$ $48.699 T+68.538, n=10, R^{2}=0.8142, p<$ $0.01)$, 与海拔 $(A)$ 和降雨量 $(P)$ 存在显著的线性负 相关 $\left(L=-0.2735 A+1341.8, n=10, R^{2}=0\right.$. $7412, p<0.01 ; L=-0.7051 P+2237.8, n=10$, $\left.R^{2}=0.4379, p<0.05\right)$ 。这一地区旱季山地雨林与 季节雨林雨量相近, 雨季期间山地雨林降雨量较季 节雨林高, 但此时两种林水分都充足, 山地雨林较高 的年降雨量对提高生产力不起作用。因此, 可以认 为在印度季风气候下云南热带雨林凋落量变化的主 要影响因子是温度,海拔增高导致温度降低使得调 落量减少。

\section{3 调落的季节性及其随海拔的变化}

在马来西亚沙捞越, 低地雨林凋落进程出现的 明显的季节性调落高峰是与较高的降雨同步 (Proctor et al. , 1983)。在印度卡纳塔克邦 (Karnataka)、高 止山脉西面 (Western Ghats) 和东北等地观测到旱季 时森林出现明显的季节性调落高峰 (Rai \& Proctor,

1986; Kumar \& Deepu, 1992; Arunachalam et al., 1998; Sundarapandian \& Swamy, 1999), 这些地区气候 受季风控制, 5 10 月印度季风期间降雨丰富, 而 11 月～翌年 4 月间为干季。西双版纳热带季节雨林和 山地雨林在旱季调落增加, 调落高峰在 $1 \sim 4$ 月, 调 落的季节模式与印度季风气候环境下的雨林、湿性 落叶林和亚热带森林的调落进程类似（Rai \& Proctor，1986; Kumar \& Deepu，1992)。表明印度季风气 候环境下季节性的水分胁迫是导致西双版纳热带雨 林在旱季出现明显调落高峰的原因。

本研究中海拔 625 1820 $\mathrm{m}$ 的季节雨林和山地 雨林在旱季都出现调落高峰, 与牙买加和新几内亚 的一些山地雨林的研究结果类似 (Tanner, 1980; Edwards, 1977), 但是高峰时间随海拔升高而变化。样 地海拔由 $625 \sim 680 \mathrm{~m}$ 增高到 1 105、1 610 和 1720 $\mathrm{m}$, 调落高峰时间提前, 原因是山地 $2 \sim 4$ 月空气湿 度急剧降低(图 1) 导致了水分胁迫。而海拔继续升 到 $1820 \mathrm{~m}$, 调落高峰反而推后 (图 3), 尽管海拔 $1820 \mathrm{~m}$ 样地空气湿度也低, 但旱季土壤含水量最高 (图 2), 减轻了空气湿度降低产生的水分胁迫。海 拔更高的哀牢山山地常绿阔叶林调落高峰期出现在
3 5 月( Liu et al., 2002b), 比本研究中海拔 $1820 \mathrm{~m}$ 样地的更晚。哀牢山空气相对湿度 1 月为 $80 \%, 2$ 4 月降低为 $66 \% ７ 1 \%$ (来自哀牢山森林生态系统 定位站观测), 与预宋的非常接近。深度 $0 \sim 15 \mathrm{~cm}$ 层的土壤含水量雨季为 $80 \% \sim 120 \%, 3$ 月开始明显 降低, 但 3 4 月含水量仍为 $50 \% \sim 60 \%$, 高于本研 究海拔 $1820 \mathrm{~m}$ 样地。综合以上观测结果, 我们认 为在印度季风条件下, 山地雨林调落高峰出现时间 受到空气相对湿度和土壤含水量变化的影响。海拔 $1100 \sim 1720 \mathrm{~m}$ 处受到空气水分胁迫, 调落高峰出现 提前, 海拔增加到 $1820 \sim 2500 \mathrm{~m}$, 土壤含水量持续 增加使水分胁迫减轻, 调落高峰推后。我们进一步 推测如果海拔继续增高, 调落高峰出现时间将继续 推后, 然而由于随后雨季来临使得水分胁迫解除, 调 落高峰将消失, 调落进程变得平稳。这一推测与哥 伦比亚热带山地雨林的观测结果一致 (Veneklaas, 1991 ), 在海拔 2550 和 $3370 \mathrm{~m}$ 的调落量在旱季并未 出现增加。两个梯度上的平均饱和汽压差随海拔增 加而减少, 尽管缺少土壤水分观测数据, Veneklaas (1991)推测其原因是山地雨林土壤和大气全年维持 较高的湿度。

热带季节雨林和山地雨林调落高峰变化趋势与 调落进程变异系数是随海拔增高而降低的变化趋势 相一致的(图 4)。

\section{参 考 文 献}

Anderson JM, Proctor J, Vallack HW (1983) . Ecological studies in four contrasting lowland rain forests in Gunung Mulu National Park, Sarawak III . Decomposition processes and nutrient losses from leaf litter. Journal of Ecology, 71, 503-527.

Arunachalam A, Arunachalam K, Pandey HN, Tripathi RS (1998). Fine litterfall and nutrient dynamics during forest regrowth in the humid subtropics of north-eastern India. Forest $E$ cology and Management, 110, 209 - 219.

Bray JR, Gorham E (1964). Litter production in forests of the world. Advances in Ecological Research, 2, 101 - 158.

Burghouts TBA, van Straalen NM, Bruijnzeel LA (1998). Spatial heterogeneity of element and litter turnover in a Bornean rain forest. Journal of Tropical Ecology, 14, 477 - 506.

Edwards PJ (1977). Studies of mineral cycling in a montane rain forest in New Guinea. II. The production and disappearance of litter. Journal of Ecology, 65, 971 - 992 .

Jordan CF (1971) . A world pattern in plant energetics. American Scientist, 59, $426-433$.

Kitayama K, Aiba S (2002). Ecosystem structure and productivity of tropical rain forests along altitudinal gradients with contrasting soil phosphorus pools on Mount Kinabalu, Borneo. Journal of 
Ecology, 90, 37 - 51.

Kumar MB, Deepu JK (1992) . Litter production and decomposition dynamics in moist deciduous forests of the Western Ghats in Peninsular India. Forest Ecology and Management, 50, 181 201.

Liu LH (刘伦辉) (1987). Rainforest. In: Wu ZY (吴征镒), Zhu $\mathrm{YC}($ 朱彦丞), Jiang HQ (姜汉侨) eds. Vegetation of Yunnan (云南植被). Science Press, Beijing, $97-163$. (in Chinese)

Liu W, Fox JED, Xu Z (2002a). Biomass and nutrient accumulation in montane evergreen broad-leaved forest (Lithocarpus xylocarpus type) in Ailao Mountains, SW China. Forest Ecology and Management, 158, $223-235$.

Liu W, Fox JED, Xu Z (2002b). Litterfall and nutrient dynamics in a montane moist evergreen broad-leaved forest in Ailao Mountains, SW China. Plant Ecology, 164, 157-170.

Moran JA, Barker MG, Moran AJ, Becker P, Ross SM (2000) . A comparison of the soil water, nutrient status, and litterfall characteristics of tropical heath and mixed-dipterocarp forest sites in Brunei. Biotropica, 31, 2-13.

Proctor J, Anderson JM, Fogden SCL, Vallack HW (1983) . Ecological studies in four contrasting lowland rain forests in Gunung Mulu National Park, Sarawak II . Litterfall, litter standing crop and preliminary observations on herbivory. Journal of Ecology, $71,261-283$.

Proctor J, Phillipps C, Duff GK, Heaney A, Robertson FM (1989) . Ecological studies on Gunung Silam, a small ultrabasic mountain in Sabah, Malaysia II . Some forest processes. Journal of Ecology, 77, 317 - 331 .

Rai SN, Proctor J (1986) . Ecological studies on four rainforests in Karnataka, India. I. Environment, structure, floristics and biomass. Journal of Ecology, 74, 439 - 454 .

Raich JW, Russell AE, Vitousek PM (1997). Primary productivity and ecosystem development along an elevational gradient on Mauna Loa, Hawaii. Ecology, 78, 707 - 721.

Sundarapandian SM, Swamy PS (1999). Litter production and leaf decomposition of selected tree species in tropical forests at Kodayar in the Western Ghats, India. Forest Ecology and Manage- ment, $123,231-244$.

Takyu M, Aiba S, Kitayama K (2003). Changes in biomass, productivity and decomposition along topographical gradients under different geological conditions in tropical lower montane forests on Mount Kinabalu, Borneo. Oecologia, 134, 397 - 404.

Tanner EVJ (1980). Litter in montane rain forests of Jamaican and its relation to climate. Journal of Ecology, 68, 833-848.

Tanner EVJ, Vitousek PM, Cuevas E (1998). Experimental investigation of nutrient limitation of forest growth on wet tropical mountains. Ecology, 79, 10-22.

Veneklaas EJ (1991). Litterfall and nutrient fluxes in two montane tropical rain forests, Colombia. Journal of Tropical Ecology, 7, $319-336$.

Vitousek PM, Turner DR, Parton WJ, Sanford RL (1994). Litter decomposition on the Mauna Loa environmental matrix, Hawaii: patterns, mechanisms, and models. Ecology, 75, 418-429.

Vogt KA, Grier CC, Vogt DJ (1986). Production, turnover, and nutrient dynamics of above-and belowground detritus of world forests. Advances in Ecological Research, 15, 303 - 377.

Weaver PL, Medina E, Pool D, Dugger K, Gonzales-Liboy J, Cuevas E (1986). Ecological observation in the dwarf cloud forest of the Luquillo Mountains in Puerto Rico. Biotropica, 18, 79 -85 .

Yang YG(杨一光) (1987). Nature environment condition of vegetation in Yunnan. In: Wu ZY (吴征镒), Zhu YC (朱彦丞), Jiang HQ(姜汉侨) eds. Vegetation of Yunnan (云南植被). Science Press, Beijing, 3-76. (in Chinese)

Zheng Z (郑征), Liu L(刘伦辉), He A(和爱军), Jing K(荆桂 芬) (1990). Litterfall and leaf consumption by animals in humid seasonal rainforest in Xishuangbanna, China. Acta Botanica Sini$c a$ (植物学报 $), 32,551-557$. (in Chinese with English abstract)

Zhu H (朱华) (2000). Ecology and Biogeography of the Tropical Dipterocarp Rain Forest in Xishuangbanna (西双版纳龙脑香热 带雨林生态学与生物地理学研究). Yunnan Science \& Technology Press, Kunming, 1-4. (in Chinese) 